\title{
HUBUNGAN ANTARA KANDUNGAN NITRAT DAN FOSFAT DENGAN KELIMPAHAN FITOPLANKTON DI PERAIRAN PULAU PARI, KEPULAUAN SERIBU
}

\author{
Relationship Between Content of Nitrate and Phosphate with Phytoplankton Abundance \\ in Pari Island, Thousand Islands.
}

\section{Cahya Rizqina, Bambang Sulardiono*) dan Ali Djunaedi}

Program Studi Manajemen Sumberdaya Perairan, Departemen Sumberdaya Akuatik

Fakultas Perikanan dan Ilmu Kelautan, Universitas Diponegoro

J1. Prof. Soedarto, SH, Tembalang, Semarang, Jawa Tengah - 50275, Telp/Fax. +6224 7474698

Email : cahya.rizqina@gmail.com

\begin{abstract}
ABSTRAK
Keberadaan fitoplankton dapat memberikan informasi mengenai kondisi suatu perairan, sedangkan nitrat dan fosfat mempengaruhi keberadaan fitoplankton untuk pertumbuhan dan transfer energi. Penelitian bertujuan untuk mengetahui jenis dan kelimpahan fitoplankton, mengetahui kandungan nitrat dan fosfat di perairan, serta hubungannya dengan kelimpahan fitoplankton dan mengetahui nilai indeks saprobitas perairan. Penelitian dilaksanakan pada bulan Mei Juni 2016. Materi penelitian adalah sampel fitoplankton dan sampel air untuk uji nitrat dan fosfat. Metode pengambilan sampel secara purposive sampling. Sampling dilakukan sebanyak tiga kali pada 3 stasiun. Pengambilan sampel fitoplankton menggunakan jaring plankton dengan metode sampling aktif. Sampel fitoplankton diawetkan menggunakan lugol iodine 2-3 tetes sebelum diidentifikasi di laboratorium. Uji kandungan nitrat dan fosfat dilakukan dengan skala laboratorium. Analisa data dilakukan menggunakan Microsoft Excel 2013. Hasil penelitian menunjukkan kandungan nitrat di Pulau Pari berkisar antara 0,069 - 0,088 mg/l. Kandungan nitrat tergolong cukup optimal bagi pertumbuhan fitoplankton. Kandungan fosfat berkisar antara 0,004-0,006 mg/l. Kandungan fosfat tergolong rendah namun masih dapat ditolerir oleh fitoplankton. Kelimpahan fitoplankton berkisar antara $1774-3657$ ind/1. Koefisien korelasi (r) sebesar 0,98 dan 0,905 artinya antara kandungan nitrat maupun fosfat dengan kelimpahan fitoplankton memiliki hubungan yang kuat. Nilai SI berkisar 1,28 - 1,43 dan nilai TSI berkisar 1,64 - 2,66 hal ini menunjukkan bahwa kualitas perairan Pulau Pari, dikategorikan dalam tingkat saprobitas oligosaprobik yaitu tercemar ringan sampai belum tercemar
\end{abstract}

Kata kunci: Nitrat dan Fosfat, Kelimpahan Fitoplankton, Indeks Saprobitas, Pulau Pari, Kepulauan Seribu

\begin{abstract}
The existence of phytoplankton in the waters can provide information about water quality, while nitrates and phosphates affecting the availability of phytoplankton for growth and energy transfer. This research aims to know phytoplankton abundance and kinds of phytoplankton, find out the levels of nitrates and phosphates in the water and its connection with the abundance of phytoplankton, and find out saprobics index water. The research was conducted in May - June 2016. Material used in research was sample of phytoplankton and water samples. Methods used field survey with purposive technique sampling. The activity of sampling done in three times in 3 different stasions. Collection of phytoplankton sample using plankton net and active sampling method. Phytoplankton samples preserved using 2-3 drops lugol's iodine before identified in the laboratory. Water samples to be tested it is nitrate and phosphate contents in laboratory scale. Data analysis research was done using Microsoft Excel 2013. This research shows the content of nitrate is about 0.069 to $0.088 \mathrm{mg} / \mathrm{l}$. Nitrate content is optimal for growth of phytoplankton and phosphate is about 0.004 to $0.006 \mathrm{mg} / \mathrm{l}$. Classified quite high but still can be tolerated by the phytoplankton. Phytoplankton abundance ranges from 1774 - 3657 ind/l. The correlation coefficient (r) between nitrate and phytoplankton abundance is 0,98 then between phosphate and phytoplankton abundance is 0,902. The result means both of them have a strong correlation. SI values from 1,28 to 1,43, and TSI value from 1,64 to 2,66 this show that water quality in Pari Island Thousand Island is categorized into oligosaprobic which is lightly polluted to uncontaminated.
\end{abstract}

Keywords: Nitrate and Phosphate, Phytoplankton abundance, Saprobic Index, Pari Island, Thousand Island

*) Penulis penanggungjawab

${ }^{\circ}$ Copyright by Management of Aquatic Resources (MAQUARES) 


\section{PENDAHULUAN}

Seiring dengan meningkatnya aktivitas manusia di wilayah Pulau Pari, dapat mengakibatkan berbagai dampak negatif. Akktivitas tersebut dapat berupa kegiatan pelabuhan, pemukiman, pariwisata, perhotelan, masuknya sedimen atau limbah dari daratan, dan lain-lain. Aktivitas tersebut baik secara langsung maupun tidak langsung akan berdampak terhadap keseimbangan ekosistem di kawasan perairan tersebut.

Fitoplankton bisa dijadikan indikator suatu perairan karena mobilitas yang terbatas dan cenderung pasif mengakibatkan pertumbuhannya sangat dipengaruhi kondisi lingkungan. Selain kecepatan arus, salah satu faktor yang mempengaruhi yaitu kandungan nitrat dan fosfat di perairan. Suplai dan unsur senyawa essensial kedalam suatu sistem perairan, khususnya nitrogen dan fosfat sering dilihat sebagai faktor pembatas yang mempengaruhi penyebaran dan pertumbuhan komunitas populasi fitoplankton. Nitrat dibutuhkan untuk mensintesa protein sedangkan fosfat berperan dalam transfer energi sel fitoplankton. Sehingga tinggi rendahnya kelimpahan fitoplankton bisa dilihat juga dari keberadaan unsur hara nitrat dan fosfat tersebut. Oleh sebab itu, penulis tertarik melakukan penelitian mengenai hubungan kandungan nitrat dan fosfat di perairan dengan kelimpahan fitoplankton di lokasi penelitian Pulau Pari, Kepulauan Seribu

\section{Tujuan dilakukannya penelitian ini adalah sebagai berikut:}

1. Mengetahui nitrat dan fosfat yang terkandung di perairan Pulau Pari, Kepulauan Seribu

2. Mengetahui jenis dan kelimpahan fitoplankton di perairan Pulau Pari, Kepulauan Seribu

3. Mengetahui hubungan antara kandungan nitrat dan fosfat dengan kelimpahan fitoplankton di perairan

4. Mengetahui saprobitas perairan di Pulau Pari, Kepulauan Seribu menggunakan bio-indikator fitoplankton.

\section{MATERI DAN METODE PENELITIAN}

\section{A. Materi Penelitian}

Materi penelitian ini adalah fitoplankton yang diambil dari perairan Pulau Pari, Kepulauan Seribu. Beberapa variabel kualitas air yang diukur meliputi kecerahan, kedalaman, suhu, kecepatan arus, salinitas, pH, DO, Nitrat dan Fosfat. Alat yang digunakan untuk sampling lapangan fitoplankton di Pulau Pari, Kepulauan Seribu, Jakarta yaitu Plankton Net no 25 untuk menyaring fitoplankton, bucket digunakan untuk wadah sampel pada plankton net, botol sampel $100 \mathrm{ml}$ untuk wadah sampel, kertas label, pipet tetes, kamera digital digunakan untuk dokumentasi dan alat tulis untuk mencatat hasil. Alat yang digunakan pada saat pengukuran kualitas air yaitu, thermometer untuk mengukur suhu air, Secchi disc untuk mengukur kedalaman dengan ketelitian $1 \mathrm{~cm}$, bola arus untuk mengukur kecepatan arus. Gelas ukur, erlenmeyer dan botol BOD digunakan untuk mengukur kadar oksigen terlarut, refraktometer untuk mengukur nilai salinitas, GPS yaitu untuk menentukan letak posisi geografis, $\mathrm{pH}$ paper untuk mengukur nilai $\mathrm{pH}$. Alat yang digunakan dalam penelitian di laboratorium adalah Sedgwick-Rafter digunakan sebagai alat pencacah fitoplankton, mikroskop digunakan untuk mengamati fitoplankton, cover glass digunakan untuk menutup Sedgwick-Rafter pada mikroskop, pipet tetes digunakan untuk mengambil larutan sampel fitoplankton, form identifikasi plankton dan alat tulis untuk mencatat hasil identifikasi plankton, buku identifikasi yang digunakan untuk mengidentifikasi fitoplankton.

Bahan yang digunakan dalam penelitian ini adalah sampel awetan plankton yang telah diawetkan dengan Lugol-Iodin $4 \%$. Reagen yang digunakan untuk mengukur kadar oksigen terlarut secara titrasi adalah $\mathrm{MnSO}_{4}, \mathrm{NaOH}$, $\mathrm{H}_{2} \mathrm{SO}_{4}, \mathrm{Na}_{2} \mathrm{~S}_{2} \mathrm{O}_{3}$ dan amilum. Sampel air yang diambil di lokasi penelitian untuk mengukur kadar nitrat dan fosfat.

\section{B. Metode Penelitian}

Metode yang digunakan dalam penelitian ini adalah metode survey yang bersifat deskriptif dengan tujuan untuk mengetahui gambaran suatu objek pengamatan dan dapat menjelaskan perkembangan yang terjadi pada kondisi pengamatan. Metode deskriptif bersifat studi kasus, studi kasus mempelajari objek secara mendalam pada waktu, tempat, dan populasi yang terbatas, sehingga memberikan tentang situasi dan kondisi secara lokal dan hasilnya tidak berlaku untuk tempat dan waktu yang berbeda (Hadi, 2004).

\section{Penentuan lokasi sampling}

Metode pengambilan sampel menggunakan metode purposive sampling yaitu pengambilan data dengan alasan dan pertimbangan tertentu dengan sengaja untuk mendapatkan sampel yang mewakili baik area maupun kelompok sampel sehingga didapat gambaran lokasi penelitian secara keseluruhan.

Stasiun lokasi sampling berada pada bagian barat dari pulau, hal tersebut dilakukan karena memperhatikan mudahnya medan yang akan ditempuh agar pelaksanaan pengambilan sampel dapat berjalan dengan baik. Stasiun dibagi menjadi 3.

- $\quad$ Stasiun 1 terletak di posisi selatan pulau Pari dimana perairan berbatasan langsung dengan laut lepas sehingga kondisi perairan dipengaruhi oleh kuat arus dan energi gelombang yang terjadi di daerah tersebut.

Stasiun 2 terletak di posisi utara pulau Pari dengan kondisi perairan cenderung tenang karena tertutup oleh pulau Tengah di sebrangnya dan dipengaruhi aktivitas pariwisata.

Stasiun 3 terletak di posisi barat pulau Pari dengan kondisi perairan dengan arus cenderung tenang dan jauh dari pinggir pantai. 


\section{Teknik Pengambilan Sampel}

Pengambilan sampel fitoplankton dilakukan dengan menggunakan metode sampling aktif. Sampel plankton diambil secara horizontal dengan cara menyaring air menggunakan plankton net ukuran $30 \mu \mathrm{m}$, jaring ditarik menggunakan kapal pada permukaan perairan dengan kecepatan kapal yang konstan selama 5 menit. Metode pengambilan plankton secara horizontal ini dimaksudkan untuk mengetahui sebaran plankton horizontal. Plankton net pada suatu titik di laut, ditarik menuju ke titik lain, plankton net ditarik untuk jarak dan waktu tertentu (biasanya $\pm 5-8$ menit). (Sulardiono et al., 2015)

Sampel air hasil penyaringan dimasukkan dalam botol sampel $100 \mathrm{ml}$ kemudian diberikan larutan lugol-iodin sebanyak tiga tetes.

\section{Analisa Data}

$>$ Kelimpahan fitoplankton

Perhitungan jumlah plankton per liter, digunakan rumus APHA (1989), yaitu :

$\mathrm{N}=\frac{\mathrm{T}}{\mathrm{L}} \mathrm{X} \underset{\mathrm{p}}{\mathrm{P}} \mathrm{X} \underset{\mathrm{v}}{\mathrm{V}} \mathrm{X} \frac{1}{\mathrm{w}}$

Keterangan :

$$
\begin{aligned}
& \mathrm{N}=\text { Jumlah fitoplankton per liter } \\
& \mathrm{T}=\text { Luas gelas penutup }\left(\mathrm{mm}^{2}\right) \\
& \mathrm{L}=\text { Luas lapang pandang }\left(\mathrm{mm}^{2}\right) \\
& \mathrm{P}=\text { Jumlah fitoplankton yang tercacah } \\
& \mathrm{p}=\text { Jumlah lapang pandang yang diamati } \\
& \mathrm{V}=\text { Volume sampel fitoplankton yang tersaring }(\mathrm{ml}) \\
& \mathrm{v}=\text { Volume sampel fitoplankton di bawah gelas penutup }(\mathrm{ml}) \\
& \mathrm{w}=\text { Volume sampel fitoplankton yang disaring (liter) }
\end{aligned}
$$

\section{$>\quad$ Uji regresi}

Analisa data yang digunakan untuk mengetahui hubungan antara nitrat dan fosfat dengan kelimpahan fitoplankton adalah dengan analisa regresi linier berganda menggunakan Microsoft Excel 2013.

\section{HASIL DAN PEMBAHASAN}

Hasil

\section{A. Deskripsi lokasi}

Pulau Pari adalah suatu wilayah yang berada di Kepulauan Seribu, DKI Jakarta. Terdiri dari Pulau Pari, Pulau Kongsi, Pulau Tengah, Pulau Burung, dan Pulau Tikus. Secara geografis Pulau Pari terletak antara $05^{\circ}$ 50' LS hingga $05^{\circ} 53^{\prime}$ LS dan $106^{\circ} 34^{\prime}$ BT sampai $106^{\circ} 38^{\prime}$ BT. Daerah ini terletak di Laut Jawa, di sebelah Utara DKI Jakarta dan Tangerang. Pulau Pari memiliki panjang garis pantai $8,5 \mathrm{~km}$, topografi yang berbentuk datar (ketinggian $\pm 0-3 \mathrm{~m} \mathrm{dpl)}$ dengan tipe pantai berpasir putih dan bervegetasi lamun dan mangrove. Pulau ini memiliki perairan dangkal dengan

\begin{tabular}{|c|c|c|c|c|c|}
\hline \multirow{2}{*}{ Parameter } & \multicolumn{3}{|l|}{ Stasiun } & \multirow{2}{*}{$\begin{array}{c}\text { Nilai } \\
\text { optimum }\end{array}$} & \multirow{2}{*}{ Pustaka } \\
\hline & Stasiun 1 & Stasiun 2 & Stasiun 3 & & \\
\hline Suhu air $\left({ }^{\circ} \mathrm{C}\right)$ & 28 & 30 & 31 & $28-30$ & Dahuri, 2003 \\
\hline Salinitas (\%) & 30 & 30 & 30 & $10-40$ & Dahuri, 2003 \\
\hline Kec. Arus (m/s) & 0,11 & 0,099 & 0,072 & $0,025-0,050$ & Mason, 1981 \\
\hline Kedalaman $(\mathrm{cm})$ & 96 & 114 & 130 & - & - \\
\hline $\mathrm{pH}$ & 8 & 8 & 8 & 8 & Alongi, 1998 \\
\hline $\mathrm{DO}(\mathrm{mg} / \mathrm{l})$ & 3,6 & 3,2 & 3,2 & Min. 3 & Pescod, 1973 \\
\hline Nitrat (mg/l) & 0,071 & 0,069 & 0,088 & 0,008 & $\begin{array}{l}\text { Kepmen LH } 51 \\
\text { Tahun } 2004\end{array}$ \\
\hline Fosfat (mg/l) & 0,004 & 0,004 & 0,005 & 0,015 & $\begin{array}{l}\text { Kepmen LH } 51 \\
\text { Tahun } 2004\end{array}$ \\
\hline
\end{tabular}
substrat berpasir pada bagian barat dan pasir halus berlumpur pada bagian utara. (http://www.ppk-kp3k.kkp.go.id/)

\section{B. Pengukuran Kualitas Air Lokasi Penelitian}

Berdasarkan hasil pengukuran parameter kualitas air perairan Pulau Pari, Kepulauan Seribu yang tersaji pada Tabel 1 dibawah ini, memiliki kisaran suhu $28-31^{\circ} \mathrm{C}$, salinitas $30 \%$, kecepatan arus berkisar antara $0,072-0,11 \mathrm{~m} / \mathrm{s}$, $\mathrm{pH} 8$, oksigen terlarut (DO) 3,2-3,6 mg/l, nitrat $0,071-0,088 \mathrm{mg} / \mathrm{l}$ dan fosfat $0,004-0,005 \mathrm{mg} / \mathrm{l}$. Kualitas air masingmasing stasiun masih berada pada kisaran nilai optimum dan tidak ada perbedaan yang mencolok.

Tabel 1. Hasil rerata pengukuran kualitas air di perairan Pulau Pari, Kepulauan Seribu 


\section{Jenis dan kelimpahan fitoplankton}

Tabel 2. Jenis dan Kelimpahan Fitoplankton di Perairan Pulau Pari

\begin{tabular}{|c|c|c|c|c|}
\hline \multirow{2}{*}{ No. } & \multirow{2}{*}{ Kelas } & \multicolumn{3}{|c|}{ Kelimpahan Fitoplankton (Ind/L) } \\
\hline & & Stasiun 1 & Stasiun 2 & Stasiun 3 \\
\hline & Bacillariophyceae & & & \\
\hline 1. & Bacteriastrum & 46 & 56 & 67 \\
\hline 2. & Biddulphia & - & 26 & 67 \\
\hline 3. & Chaetoceros & 414 & 247 & 139 \\
\hline 4. & Coscinodiscus & 245 & 117 & 129 \\
\hline 5. & Gyrosigma & - & 43 & 62 \\
\hline $6 .$. & Leptocylindrus & - & 22 & 33 \\
\hline 7. & Nitzschia & 339 & 412 & 1626 \\
\hline 8. & Pleurosigma & 62 & 69 & 62 \\
\hline 9. & Rhizosolenia & 46 & 91 & 239 \\
\hline 10. & Skeletonema & 219 & 273 & 239 \\
\hline 11. & Synedra & 42 & 43 & 134 \\
\hline 12. & Thallassionema & - & 39 & 57 \\
\hline 13. & Thallassiothrix & - & 22 & 33 \\
\hline \multirow[t]{2}{*}{14.} & Triceratium & - & 13 & 19 \\
\hline & Chlorophyceae & & & \\
\hline \multirow[t]{2}{*}{15} & Closterium & 49 & - & 115 \\
\hline & Cyanophycae & & & \\
\hline \multirow[t]{2}{*}{16.} & Trichodesmium & 519 & 204 & 521 \\
\hline & Dinophyceae & & & \\
\hline \multirow{2}{*}{17.} & Ceratium & 29 & 95 & 115 \\
\hline & Jumlah & 2010 & 1772 & 3657 \\
\hline
\end{tabular}

Keterangan (-) $=$ Tidak Tercacah

Kelimpahan fitoplankton yang didapatkan berdasarkan Tabel 2 diatas yaitu terdapat kelimpahan sebanyak 2010 ind/L pada stasiun 1, stasiun 2 terdapat 1772 ind/L dan stasiun 3 memiliki kelimpahan fitoplankton tertinggi yaitu 3657 ind/L. Jenis fitoplankton yang didapatkan dari tiga stasiun selama penelitian terdiri dari 4 kelas dan 17 genera, yaitu kelas Bacillariophycae (14 genera), kelas Chlorophychea (1 genus), kelas Cyanophycae (1 genera) dan kelas Dinophyceae (1 genera). Jenis yang paling sering muncul yaitu Nitzschia dan Tricodesmium.

\section{Hubungan Kelimpahan Fitoplankton Dengan Kandungan Nitrat dan Fosfat}

Grafik hubungan antara nilai kandungan nitrat dan perairan dengan kelimpahan fitoplankton disajikan dalam Gambar 1 .

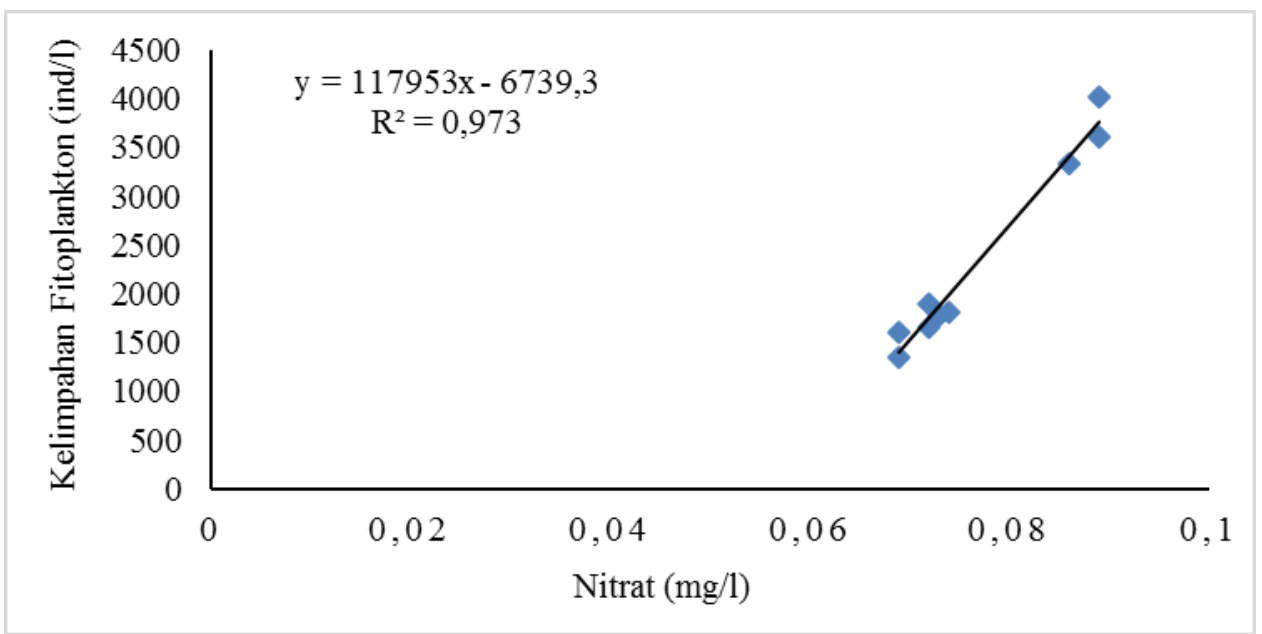

Gambar 1. Grafik hubungan kelimpahan fitoplankton dengan kandungan nitrat perairan

Berdasarkan Gambar 1. Hubungan antara kelimpahan fitoplankton dengan kandungan nitrat perairan membentuk persamaan $\mathrm{y}=106082 \mathrm{x}-5688,7$ dari persamaan diketahui koefisien regresi variabel nitrat $(\mathrm{x})$ sebesar 106082, artinya setiap kenaikan konsentrasi nitrat $0,1 \mathrm{mg} / \mathrm{l}$ akan mengakibatkan peningkatan kelimpahan fitoplankton (y) sebanyak 106,08 ind/l. Koefisien bernilai positif artinya terjadi hubungan positif antara kandungan nitrat dengan kelimpahan fitoplankton. Nilai koefisien determinasi $\left(R^{2}\right)=0,973$ hasil ini menunjukan bahwa kelimpahan fitoplankton $97,3 \%$ dipengaruhi oleh nilai kandungan nitrat dan 2,7\% dipengaruhi oleh hal lain. 
Grafik hubungan antara nilai kandungan fosfat perairan dengan kelimpahan fitoplankton disajikan dalam Gambar 2 dibawah ini.

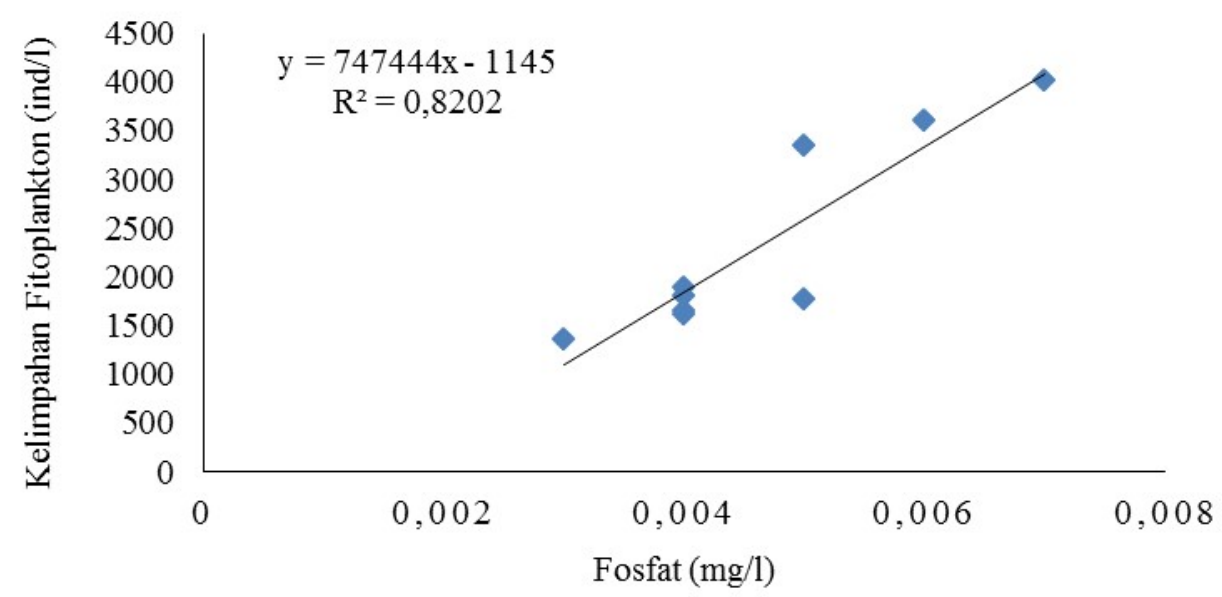

Gambar 2. Grafik hubungan kelimpahan fitoplankton dengan kandungan fosfat perairan

Berdasarkan Gambar 4 hubungan antara kelimpahan fitoplankton dengan kandungan fosfat di perairan membentuk persamaan $\mathrm{y}=747444 \mathrm{x}-1145$ dari persamaan diketahui koefisien regresi variabel fosfat $(\mathrm{x})$ sebesar 747444, artinya setiap kenaikan konsentrasi fosfat $0,001 \mathrm{mg} / \mathrm{l}$ akan mengakibatkan peningkatan kelimpahan fitoplankton (y) sebanyak 747,44 ind/1. Nilai koefisien determinasi $\left(\mathrm{R}^{2)}=0,8202\right.$ hasil ini menunjukan bahwa kelimpahan fitoplankton 82,02\% dipengaruhi oleh kandungan fosfat dan 17,98\% dipengaruhi oleh hal lain. Koefisien bernilai positif artinya terjadi hubungan positif antara kandungan fosfat dengan kelimpahan fitoplankton.

\section{E. Indeks Saprobitas}

Hasil pengamatan saprobitas perairan di perairan Pulau Pari disajikan pada Tabel 3. Tabel 3. Nilai SI dan TSI di Perairan Pulau Pari

\begin{tabular}{cccc}
\hline & Stasiun 1 & Stasiun 2 & Stasiun 3 \\
\hline SI & 1,28 & 1,43 & 1,43 \\
TSI & 2,66 & 2,16 & 1,64 \\
\hline
\end{tabular}

Nilai SI pada tiga stasiun berturut-turut $1,28-1,43-1,43$ serta nilai TSI berturut-turut yaitu 1,6 - 2,16-2,66 . Nilai tersebut menunjukkan bahwa tingkat pencemaran perairan termasuk ringan sampai sedang. Hal ini dikarenakan pada saat pagi hari intensitas cahaya matahari sangat optimal untuk melakukan fotosintesis bagi fitoplankton sehingga menghasilkan nutrien yang cukup besar, selain itu di lokasi sampling belum dimulainya kegiatan pariwisata maupun aktivitas dari para pedagang sekitar. Sehingga kondisi perairan masih tampak cukup bersih dan belum banyak tercemar. Jumlah nutrien merupakan faktor pendukung produktifitas perairan (Mortazavi et al., 2000).

\section{Pembahasan}

\section{A. Jenis dan kelimpahan fitoplankton}

Berdasarkan hasil identifikasi fitoplankton dan perhitungan kelimpahan didapatkan jumlah dan jenis fitoplankton yang ditemukan di perairan Pulau Pari terdiri dari 4 kelas dan 17 genera, yaitu kelas Bacillariophyceae (14 genus), kelas Chlorophyceae (1 genus), kelas Cyanophycae (1 genus) dan kelas Dinophyceae (1 genus). Kelas Bacillariophyceae (diatom) paling banyak ditemukan baik di stasiun 1, stasiun 2 maupun stasiun 3.

Kelimpahan fitoplankton didefenisikan sebagai jumlah individu plankton per satuan volume air dan dinyatakan dalam jumlah sel per liter air. Variasi musiman kelimpahan plankton di daerah subtropis sangat nyata sekali, tetapi di daerah tropis variasi musiman kurang menonjol. Umumnya pada variasi musiman kelimpahan fitoplankton di daerah tropis bukan disebabkan oleh perubahan suhu tetapi karena adanya pergantian arah angin (Raymont, 1984).

Hasil yang diperoleh selama pengamatan rata-rata kelimpahan Fitoplankton pada stasiun 3 adalah 3657 ind/l, pada stasiun 2 rata-rata kelimpahan fitoplankton adalah 1772 ind/l. Sedangkan pada stasiun 1 adalah 2010 ind/l. Hasil penelitian memperlihatkan bahwa pada stasiun 1 dan 2 menunjukkan adanya sedikit perbedaan jumlah kelimpahan, sedangkan untuk stasiun 3 memiliki kelimpahan hampir dua kali lipat dari stasiun lainnya. Hal tersebut bisa diperkirakan karena adanya perbedaan arus, selain itu, fitoplankton merupakan makanan bagi ikan herbivor dan bentos sehingga ketersediaannya berpengaruh bagi komunitas pada tingkat trofik di atasnya. Keberadaannya di lingkungan perairan berkaitan dengan alam atau habitat, faktor pembatas seperti cahaya, nutrien, grazing, dan substrat.

Stasiun 1, stasiun 2 maupun stasiun 3, kelas Bacillariohyceae selalu memiliki kelimpahan tertinggi dari kelas lainnya yaitu Chlorophyceae, Cyanophyceae, dan Dinophycheae. Tingginya kelimpahan fitoplankton dari kelas Bacillariophyceae dikarenakan kelas Bacillariophyceae mampu menyesuaikan diri dengan kondisi lingkungan 
sekitarnya sehingga dapat berkembang biak dengan cepat dibandingkan dengan kelas lainnya. Menurut Arinardi et al (1997), kelas Bacillariophyceae lebih mampu beradaptasi dengan kondisi lingkungan yang ada, kelas ini bersifat kosmopolitan serta mempunyai toleransi dan daya adaptasi yang tinggi.

Kelimpahan dari kelas Chlorophyceae, Cyanophyceae, Dinophyceae yang ditemukan tidak sebanyak kelas Bacillariophyceae dan hanya ditemukan 1 genus. Hal ini sesuai dengan Nontji (2006) yang menyatakan bahwa Cyanophyceae biasanya jarang dijumpai, tetapi kadang-kadang akan muncul tiba-tiba dalam ledakan populasi yang amat besar dan tak lama kemudian akan menghilang lagi dengan sangat cepat. Sedangkan kelas Dinophyceae paling sedikit ditemukan daripada kelas fitoplankton lainnya karena perkembangbiakannya lebih lambat dibandingkan dengan perkembangbiakan kelas lainnya.

Jenis fitoplankton yang paling sering muncul di lokasi penelitian selama pengamatan ialah Nitzschia dari kelas Bacillariophyceae. Hal ini menjadikan Nitzschia berperan cukup tinggi dalam menjaga keberlangsungan ekosistem perairan di lokasi ini. Nitzschia merupakan salah satu spesies yang memiliki toleransi dan adaptasi yang tinggi terhadap lingkungan perairan sehingga dapat hidup pada lingkungan yang tercemar sekalipun.

Jenis lainnya yang sering muncul yaitu Tricodesmium, kelimpahan dari Tricodesmium yaitu mencapai 521 ind/l yang didapatkan pada stasiun 3, sedangkan pada stasiun 2 didapatkan 204 ind/l. Perbedaan kelimpahan pada kedua stasiun kemungkinan disebabkan karena adanya perbedaan unsur hara dan suhu perairan. Keberadaan Tricodesmium. Di perairan perlu diwaspadai karena dapat menyebabkan penurunan oksigen terlarut. Penurunan oksigen dapat menyebabkan gangguan pada biota lain yang terdapat di perairan tersebut karena akan menyebabkan adanya kompetisi konsumsi oksigen. Menurut Wiadnyana (1996), spesies yang menyebabkan penurunan oksigen terlarut disebut spesies "anoxious". Kelompok "anoxious" yang paling sering ditemukan adalah Tricodesmium erytrhraeum. Penurunan oksigen secara drastis dapat menyebabkan kematian masal ikan dan vertebrata sehingga dapat mengganggu stabilitas perairan. Hal ini diperkuat oleh Sediadi (2014), karakteristik lain Tricodesmium $s p$. yang harus diwaspadai adalah pada saat melimpah (blooms) di perairan tropis, yaitu dapat meneyebabkan kuranngnya kandungan oksigen sehingga terjadi proses pembusukan yang akhirnya dapat menimbulkan kematian biota laut, seperti ikan.

\section{B. Kandungan nitrat dan fosfat di perairan}

Nilai nitrat yang terkandung di perairan Pulau Pari yaitu $0,071-0,088 \mathrm{mg} / \mathrm{L}$, secara umum nilai tersebut masih diatas kandungan nitrat yang umum dijumpai di perairan laut. Kandungan nitrat yang normal di perairan laut umumnya berkisar antara 0,01-50 $\mu \mathrm{g} / \mathrm{l}$ atau setara dengan 0,00014-0,7 mg/l (Edward dan Tarigan dalam Patty, 2015).

KLH (2004) menetapkan standar baku mutu senyawa nitrat untuk biota laut sebesar $0,008 \mathrm{mg} / \mathrm{l}$. Sedangkan Effendi dalam Simanjuntak (2012) menyatakan kadar nitrat perairan $>0,2 \mathrm{mg} / \mathrm{l}$ dapat mengakibatkan terjadinya eutrofikasi yang dapat merangsang pertumbuhan fitoplankton dengan cepat (blooming). Bila ditinjau dari kadar nitrat yang merupakan salah satu indikator kesuburan, maka kisaran kadar nitrat di perairan Pulau Pari masih dalam batas aman kesuburan suatu perairan.

Nilai fosfat yang terkandung di perairan Pulau Pari sebesar 0,004 - 0,005 mg/L. Nilai ini tergolong relatif rendah. Dalam keputusan MENLH No.51 Tahun 2004, disebutkan bahwa baku mutu konsentrasi fosfat yang layak untuk kehidupan biota laut adalah $0,015 \mathrm{mg} / \mathrm{L}$. Data penelitian menunjukkan bahwa konsentrasi fosfat jauh lebih rendah dari batasan konsentrasi yang dipersyaratkan. Rendahnya kandungan fosfat bisa terjadi karena perbedaan stratifikasi pengambilan sampel.

Secara alamiah fosfat terdistribusi mulai dari permukaan sampai dasar. Semakin ke dasar semakin tinggi konsentrasinya sebagai akibat dari dasar laut yang kaya akan nutrisi dan konsentrasinya semakin rendah semakin jauh ke arah laut. Rendahnya kadar fosfat di lapisan permukaan kemungkinan dapat pula disebabkan oleh aktifitas fitoplankton yang intensif (Muchtar dan Simanjuntak, 2008).

Menurut Mackentum dalam Basmi (1999), senyawa ortofosfat merupakan faktor pembatas bila kadarnya di bawah 0,004 ppm, sementara pada kadar lebih dari 1,0 ppm PO4- dapat menimbulkan blooming.

\section{Hubungan Antara Kelimpahan Fitoplankton Dengan Kandungan Nitrat dan Fosfat}

Hubungan kelimpahan fitoplankton dan konsentrasi nitrat di perairan Pulau Pari, Kepulauan Seribu ini melalui analisis regresi linier sederhana menunjukkan korelasi positif dengan persamaan linier $\mathrm{y}=117953 \mathrm{x}-6739,3$, koefisien determinasi $\left(\mathrm{R}^{2}\right)=0,973$ dan koefisien korelasi $(\mathrm{r})=0,98$. Dari persamaan regresi linier sederhana tersebut diketahui bahwa hubungan konsentrasi nitrat dan kelimpahan fitoplankton di perairan Pulau Pari, Kepulauan Seribu adalah berbanding lurus, artinya meningkatnya konsentrasi nitrat di perairan tersebut maka kelimpahan fitoplankton akan meningkat. Nilai koefisien determinasi $\left(\mathrm{R}^{2}\right)$ yaitu 0,973 , hasil ini menunjukan bahwa kelimpahan fitoplankton $97,3 \%$ dipengaruhi oleh nilai kandungan nitrat dan 2,7\% dipengaruhi oleh hal lain. Nilai koefisien korelasi $(r=0,98)$ menunjukkan hubungan yang kuat.

Hubungan kelimpahan fitoplankton dan konsentrasi fosfat di perairan Pulau Pari, Kepulauan Seribu melalui analisis regresi linier sederhana menunjukkan korelasi positif dengan persamaan linier $\mathrm{y}=747444 \mathrm{x}-1145$, koefisien determinasi $\left(\mathrm{R}^{2}=0,8202\right)$ dan koefisien korelasi $(\mathrm{r}=0,902)$. Dari persamaan regresi linier sederhana tersebut diketahui bahwa hubungan konsentrasi fosfat dan kelimpahan fitoplankton di perairan Pulau Pari, Kepulauan Seribu adalah berbanding lurus, artinya meningkatnya konsentrasi fosfat di perairan tersebut maka kelimpahan fitoplankton akan meningkat. Nilai koefisien determinasi $\left(\mathrm{R}^{2}\right)$ yang didapatkan pada hubungan konsentrasi fosfat dengan kelimpahan fitoplankton yaitu 0,8202 hasil ini menunjukan bahwa kelimpahan fitoplankton $82 \%$ dipengaruhi oleh nilai kandungan 
nitrat dan 18\% dipengaruhi oleh hal lain. Nilai koefisien korelasi

$(\mathrm{r}=0,902)$ menunjukkan hubungan yang

kuat.

Menurut Tataming et al., (2014) koefisien korelasi digunakan untuk mengetahui kuatnya hubungan antara variabel dependen dengan variabel independen diukur dengan koefisien korelasi (r) adalah suatu ukuran relatif dari asosiasi diantara dua variabel. Sedangkan menurut Riduwan (2003) dalam Rosyid dan Sukandi (2012), interval koefisien korelasi nilai $\mathrm{r}$ antara 0,800-1,00 menunjukan tingkat hubungan yang sangat kuat.

\section{Indeks saprobitas}

Indeks Saprobitas yang didapat pada stasiun 1 yaitu 2,17 dan 1,43 untuk masing-masing stasiun 2 dan 3. Nilai TSI untuk stasiun 1, stasiun 2 dan stasiun 3 berturut-turut adalah 2,66 2,16 dan 1,64. Berdasarkan nilai saprobitas yang didapatkan diketahui bahwa status perairan Pulau Pari masih termasuk dalam kriteria Oligosaprobik, dengan indikasi pencemaran pada perairan tersebut masih sangat ringan atau sama sekali belum tercemar sehingga kesuburan perairan masih dapat dimanfaatkan. Menurut Lee et al., (1978) dalam Anggoro (1988), suatu perairan dengan nilai SI dan TSI 1,5 - 2 tergolong dalam kelompok oligosaprobik yang berarti bahwa kondisi perairan tersebut tercemar ringan sampai atau belum tercemar. Hasil yang didapat tersebut berdasarkan sifat distribusi plankton yang dipengaruhi oleh arus dan aktivitas pasang surut

Menurut Hawkes (1978), kecepatan arus akan berperan dalam proses migrasi dan penyebaran plankton sebagai organisme yang pasif sehingga pergerakannya sangat ditentukan oleh arus. Hal ini berarti kecepatan arus akan mempengaruhi komposisi dan kelimpahan plankton. Perbedaan jumlah organisme plankton dalam suatu perairan akan mempengaruhi tingkat saprobitas di perairan tersebut. Nilai saprobitas perairan merupakan gambaran dari tingkat pencemaran suatu perairan yang diukur dari kandungan nutrient dan bahan pencemar. Namun, kandungan nutrient yang cukup akan meningkatkan produktifitas fitoplankton. Meningkatnya produktifitas fitoplankton akan mendukung meningkatnya produktifitas organisme lain yang memiliki tingkatan trofik lebih tinggi (Chanton dan Lewis, 2002).

\section{KESIMPULAN}

Kesimpulan yang diperoleh dari penelitian ini adalah sebagai berikut:

1. Konsentrasi nitrat di perairan Pulau Pari berkisar antar 0,071 - 0,088 mg/l, kandungan nitrat tergolong cukup optimal bagi pertumbuhan fitoplankton sedangkan fosfat yaitu $0,004-0,006 \mathrm{mg} / \mathrm{l}$, kandungan fosfat tergolong rendah namun masih dapat ditolerir oleh fitoplankton

2. Kelimpahan fitoplankton yang didapatkan yaitu 1772 - 3657 ind/1, terdiri dari 4 kelas yaitu kelas Bacillariophyceae, Chlorophycae, Cyanophycae dan Dinophyceae. Genera terbanyak dari kelas Bacillariophyceae (diatom), karena diatom mempunyai toleransi dan daya adaptasi yang tinggi.

3. Koefisien korelasi (r) antara nitrat dan fosfat dengan kelimpahan fitoplankton yaitu 0,98 dan 0,905 . Koefisien korelasi dengan nilai $r$ antara 0,800-1,00 menunjukan tingkat hubungan yang sangat kuat. Hal tersebut mengindikasikan jika semakin tingginya nutrien di perairan akan diikuti oleh peningkatan kelimpahan fitoplankton.

4. Saprobik Indeks (SI) berkisar 1,43 - 2,17 dan Tropik Saprobik Indeks (TSI) berkisar 1,64 - 2,66. Nilai tersebut menunjukkan bahwa kualitas perairan di Pulau Pari, Kepulauan Seribu dikategorikan dalam tingkat saprobitas Oligosaprobik yaitu perairan tercemar ringan atau belum tercemar.

\section{UCAPAN TERIMA KASIH}

Penulis mengucapkan terima kasih kepada Allah SWT yang telah memberikan rahmat dan karunia-Nya sehingga penulis dapat menyelesaikan penelitian ini. Terima kasih Ir. Siti Rudiyanti, M.Si, Dr. Ir Suryanti, M.Pi, Dr. Ir. Pujiono W. Purnomo, MS untuk saran dan masukannya di dalam penyusunan penulisan ini. Serta kepada seluruh pihak yang membantu selama penelitian ini.

\section{DAFTAR PUSTAKA}

Anggoro, S. 1983. Tropic Saprobic Analisis : Metode Evaluasi Kelayakan Lokasi Budidaya Biota Aquatic. Jurusan Ilmu Perairan. Fakultas Pasca Sarjana. IPB, Bogor.

1988. Analisa Tropik-Sapronik (Trosap) Untuk Menilai Kelayakan Lokasi Budidaya Laut dalam : Workshop Budidaya Laut Perguruan Tinggi Se-Jawa Tengah. Laboratorium Pengembangan Wilayah Pantai. Universitas Diponegoro, Semarang. Hal. 66-90.

APHA (American Public Health Association). 1989. Standard Method for the Examinition of Water and Waste Water. American Public Health Association. Water Pollution Control Federation. Port City Press. Baltimore, Mariland.1202 p.

Apridayanti, E. 2008. Evaluasi Pengelolaan Lingkungan Perairan Waduk Lahor Kabupaten Malang Jawa Timur. Tesis Ilmu Lingkungan Universitas Diponegoro. Semarang. 
Arinardi, O.H., A.B. Sutomo, S.A. Yusuf, Trimaningsih, E., Asnaryanti dan S.H. Riyono. 1997. Kisaran Kelimpahan dan Komposisi Plankton Predominan di Perairan Kawasan Timur Indonesia. Pusat Penelitian dan Pengembangan Oseanografi LIPI, Jakarta.

Barus. 2002. Pengantar Limnologi. Jurusan Biologi FMIPA Universitas Sumatra Utara. Medan.

Basmi. 2000. Planktonologi : Sebagai Indikator Pencemaran Perairan. Fakultas Perikanan dan Ilmu Kelautan. Institut Pertanian Bogor, Bogor.

Chanton, J. and F. G. Lewis. 2002. Examination of coupling between primary and secondary production in a river dominated estuary: Apalachicola Bay, Florida, U.S.A. Limnology and Oceanography 47:683-697.

Hadi, S. 1982. Metodologi Research. Jilid II. Fakultas Psikologi Universitas Gajah Mada, Yogyakarta.

Hawkes, H.A. 1978. Invertebrate as Indicator of River Water Quality. University of Newcastle. Upon Tyae, Newcastle.

(http://www.ppk-kp3k.kkp.go.id/)

Mortazavi, B., R. L. Iverson, W. R. Huang, F. G. Lewis, and J. M. Caffrey. 2000b. Nitrogen budget of Apalachicola Bay, a bar built estuary in the northeastern Gulf of Mexico. Marine Ecology Progress Series 195:1-14.

Nontji. 2006. Tiada Kehidupan di Bumi Tanpa Keberadaan Plankton. Lembaga Ilmu Pengetahuan Indonesia. Jakarta.

Odum, E.P. 1993. Dasar-Dasar Ekologi. Edisi ketiga . Gajah mada University Press. Jogjakarta. H. 134-162.

Raymont, L.A., A.F. Vézina, K. Fennel., and J.J. Cullen. 1984. The Ecology of Freshwater Phytoplankton. University Pierre et Marie Curie. Paris.

Rosyid, F. A. dan P. Sukandi. 2012. Pengaruh Store Athmosphere terhadap Keputusan Pembelian The Original Fanshop Mobile Store. Universitas WIdyatama, Bandung. ISSN: No 2089-1040.

Sediadi, A. 2004. Dominasi Cyanobacteria pada Musim Peralihan di Perairan Laut Banda dan Sekitarnya. Jurnal Makara Sains, 7 (1) : 1-14

Simanjuntak, M. 2012. Kualitas Air Laut Ditinjau dari Aspek Zat Hara, Oksigen Terlarut dan pH di Perairan Banggai, Sulawesi Tengah. Jurnal Ilmu dan Teknologi Kelautan Tropis FPIK-IPB. 4 (2): 290-303.

Sulardiono, B., Hutabarat dan A. Djunaedi. 2015. Buku Ajar Planktonologi, Universitas Diponegoro, Semarang. 117 hlm.

Tataming E. S., T.K. Sendow, O.H. Kaseke, dan S. Diantje. 2014. Analisis Besar Kontribusi Hambatan Samping Terhadap Kecepatan dengan Menggunakan Model Regresi Linier Berganda (Studi Kasus: Ruas Jalan Dalam Kota Segmen Ruas Jalan Sarapung). Jurnal Sipil Statik. 2(1): 31-32

Wiadnyana, N.N. 1996. Mikroalga Berbahaya di Perairan Indonesia, Oseaonologi dan Limnologi di Indonesia, Puslitbang Oseanologi LIPI, 29; 96 - 103. 